\title{
Hubungan Learning Approach Dengan Nilai Objective Structured Clinical Examination (OSCE) Mahasiswa Fakultas Kedokteran Universitas Riau Tahun Kedua
}

\author{
Zulfi Mustika Rantari ${ }^{1}$, Zulharman $^{2 *}$, Enikarmila Asni ${ }^{3}$
}

\begin{abstract}
The learning approach is the way to achieve their learning objectives. Learning approach can influence the OSCE value. This study aimed to analyze the relationship between learning approach and OSCE value. This study was analytic descriptive with cross-sectional design. The subjects were all the medical student University of Riau in the second year. Study Process Questionnaire (SPQ) which have been translated to Indonesia language was used in this study. OSCE value before remedial data were analyzed using Kruskal-Wallis. The majority of students $(93.1 \%)$ using the achieving approach and there were no relationship between learning approach and OSCE value. lue .
\end{abstract}

Keywords: achieving approach, deep approach, learning approach, OSCE, surface approach.

Skill lab merupakan suatu kegiatan di laboratorium dimana mahasiswa diajarkan keterampilan klinik. ${ }^{1}$ Tujuan skill lab yaitu untuk menunjang pencapaian kompetensi klinis dan dievaluasi untuk dapat meningkatkan kualitas belajar, evaluasi penilaian keterampilan klinik dilakukan dengan menggunakan metode Objective Structured Clinical Examination(OSCE). ${ }^{2}$

Objective Structured Clinical Examination adalah salah satu metode penilaian performa/kinerja mahasiswa kedokteran. ${ }^{3}$ Kegiatan ini merupakan suatu penilaian kompetensi klinik secara terencana dan terstruktur sehingga didapat objektivitas dalam penilaian. ${ }^{4}$ Anderson dan Stickery mengatakan bahwa OSCE telah digunakan di sekolah kedokteran untuk memvalidasi keterampilan klinis diberbagai kurikulum, baik untuk evaluasi formatif dan sumatif melalui penggunaan "pasien standar". ${ }^{2}$

Fakultas Kedokteran Universitas Riau (FK UNRI) merupakan salah satu perguruan tinggi yang menggunakan OSCE sebagai metode evaluasi dalam menilai keterampilan klinik mahasiswa. ${ }^{5}$ Mahasiswa membutuhkan strategi yang tepat untuk memperoleh

\footnotetext{
* Email korespondensi : dr.zulharman@gmail.com

Mahasiswa Fakultas Kedokteran Universitas Riau

2 KJFD Pendidikan Kedokteran Fakultas Kedokteran Universitas Riau

3 KJFD Biokimia Fakultas Kedokteran Universitas Riau
}

keberhasilan dalam ujian OSCE. Biggs menyatakan bahwa nilai mahasiswa dipengaruhi dari pendekatan belajar yang digunakannya. ${ }^{6}$ Pendekatan belajar atau learning approach adalah cara sesorang dalam menyelesaikan dan mencapai tujuan pembelajaran. ${ }^{7}$

Learning approach terdiri dari deep approach, surface approach dan achieving approach. Learning approach merupakan salah satu faktor internal yang mempengaruhi keberhasilan belajar mahasiwa, dimana hasil belajar seseorang dipengaruhi oleh hasil interaksi dari berbagai faktor salah satunya faktor pendekatan belajar. ${ }^{9}$ Maka dari itu peneliti melakukan penelitian ini untuk mengetahui hubungan learning approach dengan nilai OSCE mahasiswa Fakultas Kedokteran Universitas Riau tahun kedua.

\section{METODE}

Jenis penelitian yang digunakan adalah penelitian deskriptif analitik dengan pendekatan cross sectional. Subjek penelitian adalah seluruh mahasiswa tahun kedua di Fakultas Kedokteran Universitas Riau yang berjumlah 127 orang. Pengambilan sampel pada penelitian ini menggunakan metode total sampling yang dilakukan terhadap mahasiswa di Fakultas Kedokteran Universitas Riau. Variabel dependen pada penelitian ini adalah 
nilai OSCE sedangkan variabel independentnya adalah learning approach. Uji Kruskal Wallis digunakan untuk menganalisis hubungan antara learning approach dengan nilai OSCE.

\section{HASIL PENELITIAN}

Distribusi learning approach mahasiswa Fakultas Kedokteran Universitas Riau tahun kedua

Penelitian ini dilakukan pada bulan Mei 2018 sampai Juli 2018, dengan jumlah sampel sebanyak
102 orang. Sampel pada penelitian ini terdiri dari 20 subyek laki-laki dan 82 subyek perempuan mahasiswa Fakultas Kedokteran Universitas Riau tahun kedua.

Distribusi learning aproach subyek terbanyak terbanyak adalah achieving approach yang berjumlah 95 orang $(93,1 \%)$, deep approach yang berjumlah 6 orang $(5,9 \%)$ dan surface approach sebanyak 1 orang (1\%), distribusi learning approach dapat dilihat pada Tabel 1 berikut :

Tabel 1 Distribusi learning approach mahasiswa FK UNRI tahun kedua

\begin{tabular}{ll}
\hline Learning approach & Distribusi (n \%) \\
\hline Achieving & $95(93,1 \%)$ \\
Deep & $6(5,9 \%)$ \\
Surface & $1(1,0 \%)$ \\
\hline Total & $102(100 \%)$ \\
\hline
\end{tabular}

Distribusi nilai Objective Structured Clinical Examination (OSCE) mahasiswa Fakultas Kedokteran Universitas Riau tahun kedua

Distribusi nilai OSCE mahasiswa tahun kedua di Fakultas kedokteran Universitas Riau dapat dilihat pada tabel 2 berikut ini:

Table 2 Distribusi nilai OSCE mahasiswa FK UNRI tahun kedua

\begin{tabular}{cc}
\hline Nilai OSCE & Distribusi (n \%) \\
\hline $55-60$ & $3(2,9 \%)$ \\
$61-66$ & $1(1,0 \%)$ \\
$67-72$ & $4(3,9 \%)$ \\
$73-78$ & $16(15,7 \%)$ \\
$79-84$ & $20(19,6 \%)$ \\
$85-90$ & $22(21,6 \%)$ \\
$91-96$ & $27(26,5 \%)$ \\
$97-100$ & $9(8,8 \%)$ \\
\hline Total & $102(100 \%)$ \\
\hline
\end{tabular}

Berdasarkan tabel 2 dapat dilihat bahwa nilai OSCE mahasiswa terbanyak adalah pada nilai 9196 sebanyak 27 orang $(26,5 \%)$.
Hubungan learning approach dengan nilai Objective Structured Clinical Examination (OSCE) mahasiswa Fakultas Kedokteran Universitas Riau tahun kedua

Uji hipotesis yang digunakan untuk mengetahui hubungan learning approach dengan nilai OSCE mahasiswa FK UNRI tahun kedua adalah uji Kruskal-Wallis. Hasil uji statistik hubungan learning approach dengan nilai OSCE dapat dilihat pada tabel 3 : 
Tabel 3. Hasil uji hipotesis hubungan antara lerning approach dengan nilai OSCE

\begin{tabular}{llll}
\hline & Learning approach & Mean Rank & $\mathrm{p}$ \\
\cline { 2 - 4 } Nilai OSCE & DA & 43,42 & \\
& SA & 14,100 & 0,342 \\
& AA & 52,41 & \\
\hline
\end{tabular}

Berdasarkan tabel 3 didapatkan nilai $\mathrm{p}=0,342$, sehingga $p>0,05$ yang menjelaskan bahwa tidak terdapatnya hubungan signifikan antara learning approach dengan nilai OSCE mahasiswa.

\section{PEMBAHASAN}

Hasil penelitian memperlihatkan bahwa pendekatan belajar yang mendominasi mahasiswa adalah achieving approach yang diikuti deep approach dan surface approach. Hasil yang sama ditemukan pada penelitian Fitriani, Hamidy dan Masdar serta pada penelitian Papinczak. Penelitian Fitriani yang menyatakan bahwa secara umum mahasiswa kedokteran Universitas Riau tahun akademik 2011/2011 menggunakan achieving approach. ${ }^{10}$ Papinczak menyatakan bahwa mahasiswa kedokteran Universitas Queensland dengan perkuliahan PBL lebih menyukai menggunakan achieving approach dan deep approach. ${ }^{11}$

Hasil yang berbeda dengan penelitian Lisiswanti (2015) yang menyatakan bahwa deep approach yang digunakan mahasiswa Fakultas Kedokteran Universitas Lampung menempati posisi teratas yang diikuti dengan surface aproach. ${ }^{7}$ Pendekatan belajar yang berbeda-beda diantara mahasiswa dapat dipengaruhi oleh faktor personal yang juga berbeda-beda pada masing-masing mahasiswa seperti, level kemampuan pemahaman, sudut pandang terhadap pendidikan, tujuan belajar dan pengetahuan sebelumnya. ${ }^{12}$ Kek, Darmawan dan Chen mendapatkan bahwa faktor yang paling berpengaruh terhadap pendekatan belajar mahasiswa adalah lingkungan belajar. ${ }^{13}$

Ujian OSCE di FK UNRI dilaksanakan setiap akhir blok, setiap blok terdiri dari beberapa keterampilan klinis yang telah ditentukan sesuai dengan tujuan pemebelajaran blok. Mahasiswa dikatakan berhasil atau lulus jika nilai yang dicapai sudah melebihi nilai standar kelulusan yang sudah ditentukan. Nilai yang dicapai mahasiswa merupakan salah satu tolak ukur penelitian atas kemampuan, komunikasi dan keterampilan yang sudah dipelajari. ${ }^{14}$

Hasil penelitian menunjukkan bahwa beberapa mahasiswa mendapatkan nilai yang berada di rentang 61-66 sebanyak 1 orang dan 55-60 sebanyak 3 orang. Hal ini mungkin dikarenakan pengaruh dari hasil interaksi berbagai faktor yang terjadi pada tiap diri mahasiswa, diantaranya perbedaan faktor internal dan faktor eksternal. ${ }^{15}$ Tabel 2 memperlihatkan bahwa distribusi nilai OSCE terbanyak berada pada rentang nilai 91-96 sebanyak $26(26,0 \%)$ dengan menggunakan achieving approach. Karakterisktik mahasiswa dengan achieving approach dilandasi oleh faktor egoenhancement dengan cara memperoleh nilai OSCE yang tinggi. Masing-masing mahasiswa saling berkompetisi dengan lebih serius dalam belajar, disiplin, mengatur waktu dengan belajar secara teratur, rapi, sistematis dan membaca bahan bacaan yang dianjurkan dosen, dibandingkan dengan mahasiswa yang menggunakan surface approach yang memiliki motivasi ekstrinsik dengan belajar yang santai, asal menghafal, kurangnya niat untuk memahami pelajaran dan memiliki strategi belajar yang minimal. ${ }^{15}$

Berdasarkan hasil uji hipotesis KruskalWallis, diperoleh nilai $\mathrm{p}=0,342$ menunjukkan bahwa tidak terdapatnya hubungan yang bermakna antara learning approach dengan nilai OSCE. Tetapi sebanyak $85,57 \%$ mahasiswa menggunakan achieving approach. Hasil ini sama dengan penelitian Lisiwanti dkk dan penellitian Liew, Sidhu, dan Barua. Penelitian Lisiwanti menyatakan bahwa tidak terdapat hubungan yang signifikan antara pendekatan belajar dengan hasil belajar mahasiswa FK UNILA. ${ }^{7}$ Liew,Sidhu dan Barua mendapatkan bahwa gaya belajar dan pendekatan belajar tidak berkontribusi secara signifikan pada hasil belajar mahasiswa kedokteran. ${ }^{16}$ 


\section{SIMPULAN}

Distribusi learning approach yang mendominasi mahasiswa adalah achieving approach $(93,1 \%)$ diikuti deep approach (5,9\%)dan surface approach (1\%). Tidak terdapat hubungan yang bermakna antara learning approach dengan nilai OSCE mahasiswa Fakultas Kedokteran Universitas Riau tahun kedua.

\section{DAFTAR PUSTAKA}

1. Susanti MM. Implementasi pembelajaran skill laboratorium. (Studi Kasus di Program Studi DIII Keperawatan Sekolah Tinggi Ilmu Kesehatan N-NurPurwodadi) [Tesis]. Surakarta: Pasca sarjana. Universitas Sebelas Maret.; 2010

2. Ahmad C, Ahmad N, Abu Bakar R. Assesing nursing clinical skills performance using objective structure clinical examination (OSCE) for open distance learning students in open University Malaysia paper presented at the ICI9. 2009.

3. Kurniasih I. Lima komponen penting dalam perencanaan OSCE. Dental Education Unit, School of Densitry, Fakultas Kedokteran dan Ilmu Kesehatan Universitas Muhammadiyah Yogyakarta. 2014 Jan;(3):43

4. Harden RM. What is an OSCE? Med teacher, 1988;10(1):19-22

5. Universitas Riau. Buku pedoman Fakultas Kedokteran Universitas Riau. Pekanbaru : Unri Press : 2013;113-114

6. Donnon T, Hecker K. A model of approaches to learning and academic achievment of students from an inquiry based bachelor of sciences health program. Canadian J of Higher Educ. 2008; 38 (1): $1-16$

7. Lisiswanti R, Saputra O, Carolia N, Malik MM. Hubungan pendekatan belajar dan hasil belajar mahasiswa Fakultas Kedokteran Universitas Lampung. JurnalKkedokteran dan Kesehatan 2015 Jan; 79-84
8. Emilia O. Students approaches to learning. Jurnal Pendidikan Kedokteran dan Profesi Kesehatan Indonesia. 2006;1(3):61-8

9. Syah M. Psikologi belajar. Edisi ke-7. Jakarta. Raja Grafindo Persada : 2003. 145-56. 221-23

10.Fitriani A, Hamidy MY, Masdar H. Hubungan pendekatan belajar dengan prestasi akademik mahasiswa tahun kedua Fakultas Kedokteran Universitas Riau tahun akademik 2011/2012. Available from; https://repository.unri.ac.id/xmlui/ bitstream/handle/123456789/2227/ 23.pdf? sequence $=1 \&$ isAllowed $=y$

11.Papinczak T. Are deep strategic learners better suited to PBL? a preliminary study. Adv in Health SciEduc: Springer. 2009;14:337-53

12. Biggs J, Tang C. Teaching for quality learning at university. 3rdEd. New York: mcGraw-Hill; 2007. 22-3. Available from; http://books.google.co.id/ books?id $=9 \mathrm{~m} 9 \mathrm{TBX} 4 \mathrm{cWooC} \&$ printsec $=$ frontcover\& $\mathrm{h} 1=\mathrm{i} d \&$ s o u r c e $=\mathrm{g} \mathrm{b} \mathrm{s} \mathrm{g} \mathrm{e}_{-}$ summary_r\&cad $=0 \# \mathrm{v}=$ onepage $\& \mathrm{q} \& \mathrm{f}=$ false

13.Kek MA, Darmawan IGN, Chen YS. Family, learning environments, learning approaches and student outcomes in Malaysian private university. International Education Journal 2007; 8(2):31836

14. Yusuf S. Psikologi perkembangan anak remaja. Bandung: Remaja Rosdakarya. 2012; 86-89

15.Cevany W. Hubungan learning approach dengan prestasi belajar pada mahasiswa [Skripsi]. Pekanbaru: Fakultas Kedokteran Universitas Riau; 2013.

16.Liew SC, Sidhu J, Barua A. The relationship between learning preference (style and approaches) and learning outcomes among preclinical undergraduate medical student. BMC Medical Education 2015; 15(44):2-14 